\title{
Effector and memory CD4+ and CD8+ T cells in the chronic infection process
}

\author{
Dominika Ojdana', Kamil Safiejko², Alina Lipska ${ }^{3}$, Piotr Radziwon ${ }^{3}$, \\ Jacek Dadan², Elżbieta Tryniszewska1
}

${ }^{1}$ Department of Microbiological Diagnostics, Medical University of Bialystok, Poland

21st Department of General and Endocrinological Surgery, Medical University of Bialystok, Poland

${ }^{3}$ Regional Centre for Transfusion Medicine in Bialystok, Poland

\begin{abstract}
T cell memory in comparison with B cell memory is not well understood. This review focuses on CD8+ and CD4+ memory T cells. In this article we try to define memory cells and also present models of memory T cells formation. We would also like to delineate their differentiation into distinct subsets. Long-lived memory $\mathrm{T}$ cells consist in two main subsets: $\mathrm{T}_{\mathrm{CM}}$ and $\mathrm{T}_{\mathrm{EM}}$. Recent studies have shown that not all cells considered to be memory cells differentiate into $\mathrm{T}_{\mathrm{CM}}$ and $\mathrm{T}_{\mathrm{EM}}$, but a small proportion of theses cells exhibit naive cells phenotype. Memory $\mathrm{T}$ cells constitute a heterogeneous population of cells. In this study we lay stress on characteristic of main memory $\mathrm{T}$ cells subsets and their alleged participation in immune response upon reexposure to the Ag.
\end{abstract}

Key words: immune memory, memory T cells

\section{Introduction}

Mature $\mathrm{T}$ cells are produced from thymocytes as an outcome of positive and negative selection events in the thymus [1]. The death by apoptosis of thymocytes that lack T-cell receptor (TCR) specificity for selfpeptides bound to major histocompatibility complex (MHC) molecules is the result of positive selection events. Whereas, negative selection events lead to the death of cells expressing a TCR with high affinity for self MHC-self peptide complex [2].

The primary immune response is initiated in secondary lymphoid organs, where naive $\mathrm{CD} 4+$ and $\mathrm{CD} 8+$ cells encounter foreign antigens (Ags) presented by professional antigen presenting cells (APCs), in particular dendritic cells (DCs) $[3,4]$. Recognition of foreign Ags bound to cell surface MHC molecules on DCs causes selective sequestration "trapping" of recirculating $T$ cells $[5,6]$. The activation of naive $T$ cells and development of effector functions is influenced by two major factors. The first signal is via the T-cell receptor (TCR), and the second via co-stimulatory

Correspondence: E. Tryniszewska, Dept. of Microbiological Diagnostics, Medical University of Bialystok,

J. Waszyngtona Str. 15A, 15-269 Bialystok, Poland;

tel./fax: (+4885) 7468571, e-mail: zdmik@umwb.edu.pl molecule including CD28, CD11a/CD18 and CD2 [7,8]. A 24-h stimulation with Ags leads to the efficient activation of naive $\mathrm{T}$ cells and initiation of immune response $[9,10]$.

\section{Phases of the $\mathrm{T}$ cells response}

The $\mathrm{T}$ cells response to infection can be divided into three distinct phases: initial activation and expansion, contraction or death, establishment and maintenance of memory [11,12]. The initial phase lasts about a week. The expansion and differentiation of specific $\mathrm{T}$ cells into effector cells are characteristic features of this phase [2,5]. During this phase a proliferation $T$ cells occurs, which leads to a generation numerous pool of antigen specific $T$ cells. Then these cells differentiate into cells with effector properties, including a fast production of $\mathrm{Th}_{1}$ (gamma interferon (INF- $\gamma$ ), tumor necrosis factor alpha (TNF- $\alpha$ ) and interleukin 2 (IL-2)) and $\mathrm{Th}_{2}$ (IL-4, IL-10) cytokines and an enhanced synthesis of cytotoxic proteins such as granzymes, perforins [11,13].

During the next phase more than $90-95 \%$ of activated $\mathrm{T}$ cells, that participate in the primary immune response die via apoptosis once the infection is cleared $[11,12]$. This phenomenon is termed activationinduced cell death (AIC) [14]. However destruction of 
antigen-specific $\mathrm{T}$ cells at the end of immune response is not complete, and a small proportion of these cells survive and is considered to undergo additional differentiation and then enter the memory T cell pool [15-18].

The final phase is characterized by presence of a stable pool long-lived memory T cells [12]. The number of these cells is relatively constant, because of homeostatic proliferation consists of slow but steady division of memory cells $[9,11]$.

\section{Effector and memory cells, models of formation}

The characteristic feature of memory $\mathrm{T}$ cells population is their ability to survive after the completion of the immune response. These cells can persist in a host for a long time and provide long-term protection against reinfection [2,11]. Memory cells exhibit qualitative and quantitative differences in comparison with naive cells [20]. These differences cause that secondary response upon reexposure to $\mathrm{Ag}$, is faster and more efficient than the primary immune response $[10,16]$. A larger expression of adhesion molecules on the memory $\mathrm{T}$ cells surface and higher affinity of interleukin-2 receptors or the TCR cause that memory cells are activated more readily than naive cells and are able to respond to a lower dose of Ag [12]. Memory T cells exhibit an enhanced capacity and efficiency in elaboration of effector functions upon secondary challenge [19].

Precise mechanisms, conditions and signals that lead to development of effector cells or memory cells are not well understood [12]. The magnitude of the long-term memory response correlates with the number of the effector cells generated during the primary response $[21,22]$. The memory cells differentiation is a complex process regulated by intracellular and extracellular factors [21]. There are several potential models for the generation mechanisms which probably may lead to the generation of effector and memory cells while the immune response [2]:

The first model of separate precursors establishes the presence of separate naive precursors of short-lived effectors and long-lived memory cells which upon the same initial activation stimulus can differentiate into respectively effector and memory cells [2,12] (Fig. 1).

The second model establishes that $\mathrm{T}$ cells constitute uniform population of precursors, which upon distinct conditions of initial activation could become effector or memory cells [2,12] (Fig. 2).

The third one is the linear development of effector and memory T cells [24-26]. Memory cells are derived directly from effector cells [27,28], which might receive survival signals or avoid death signals. The survival of T cells can be stochastic or selective on the basis of the nature of initial activation signals [2] (Fig. 3 ). The precise selection process is not well under-

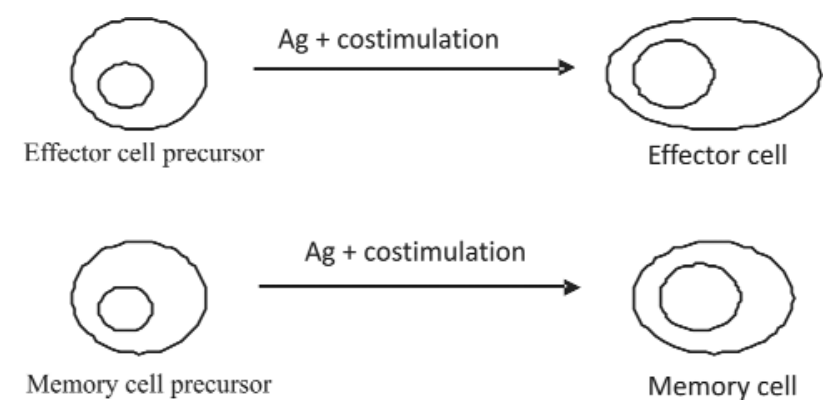

Fig. 1. The model of separate precursors [2]. Separate naive precursors of short-lived effectors and long-lived memory cells upon the same initial activation stimulus (antigen $(\mathrm{Ag})+$ costimulation) can differentiate into respectively effector and memory cells.

stood. The effector cells with higher affinity of TCR are thought to survive as memory cells [12].

The last model considers the influence of a level and time of stimulus duration for the generation of effector and memory $T$ cells $[23,29]$. A longer stimulation time provides the generation of cells more differentiated toward to effector cells. An increasing susceptibility of cells to apoptosis is accompanied [19]. The memory cells are remained at different stages of differentiation [29]. The fate of responding $\mathrm{T}$ cells depends on duration of T-cell receptor (TCR) signaling and the presence or absence of cytokines. Comparatively brief TCR stimulation leads to the generation of central memory cells $\left(\mathrm{T}_{\mathrm{CM}}\right)$. While prolonged $\mathrm{TCR}$ stimulation and the presence of cytokines may give a rise of effector memory cells $\left(\mathrm{T}_{\mathrm{EM}}\right)$ [10]. One of the factor that can influence on differentiation of $\mathrm{T}_{\mathrm{CM}}$ and $\mathrm{T}_{\mathrm{EM}}$ may be an asynchronous exposure of circulate $\mathrm{T}$ cells, related with a different strength of initial signal. The generation of $\mathrm{T}_{\mathrm{EM}}$ from naive precursors that reside in the lymph nodes while $\mathrm{Ag}$ comes in this position, while late arrivers differentiate into $\mathrm{T}_{\mathrm{CM}}[7]$.

That model of $\mathrm{T}$ cell differentiation explains the phenomenon of clonal exhaustion. That relates to an immune response, which is characterized by a strong initial T-cell activation. This leads to deletion of all responding T cells [2] (Fig. 4).

\section{Subsets of memory $T$ cells}

The memory $\mathrm{T}$ cell pool is heterogeneous in terms of it's phenotype, anatomical distribution and functional properties [30-33]. The considerable heterogeneity of the CC chemokine receptor 7 (CCR7) and L-selectin (CD62L) have been used to subdivide memory T cells into two functionally distinct $\mathrm{T}$ cells subsets $[34,35]$. Memory CD4+ T cells may be defined as central memory cells and CCR7-effector memory T cells. In addition, CCR7+ memory cells express high level of CD62L in contrast to the CCR7- memory cells, which express lower or variable level of CD62L $[30,36]$. 

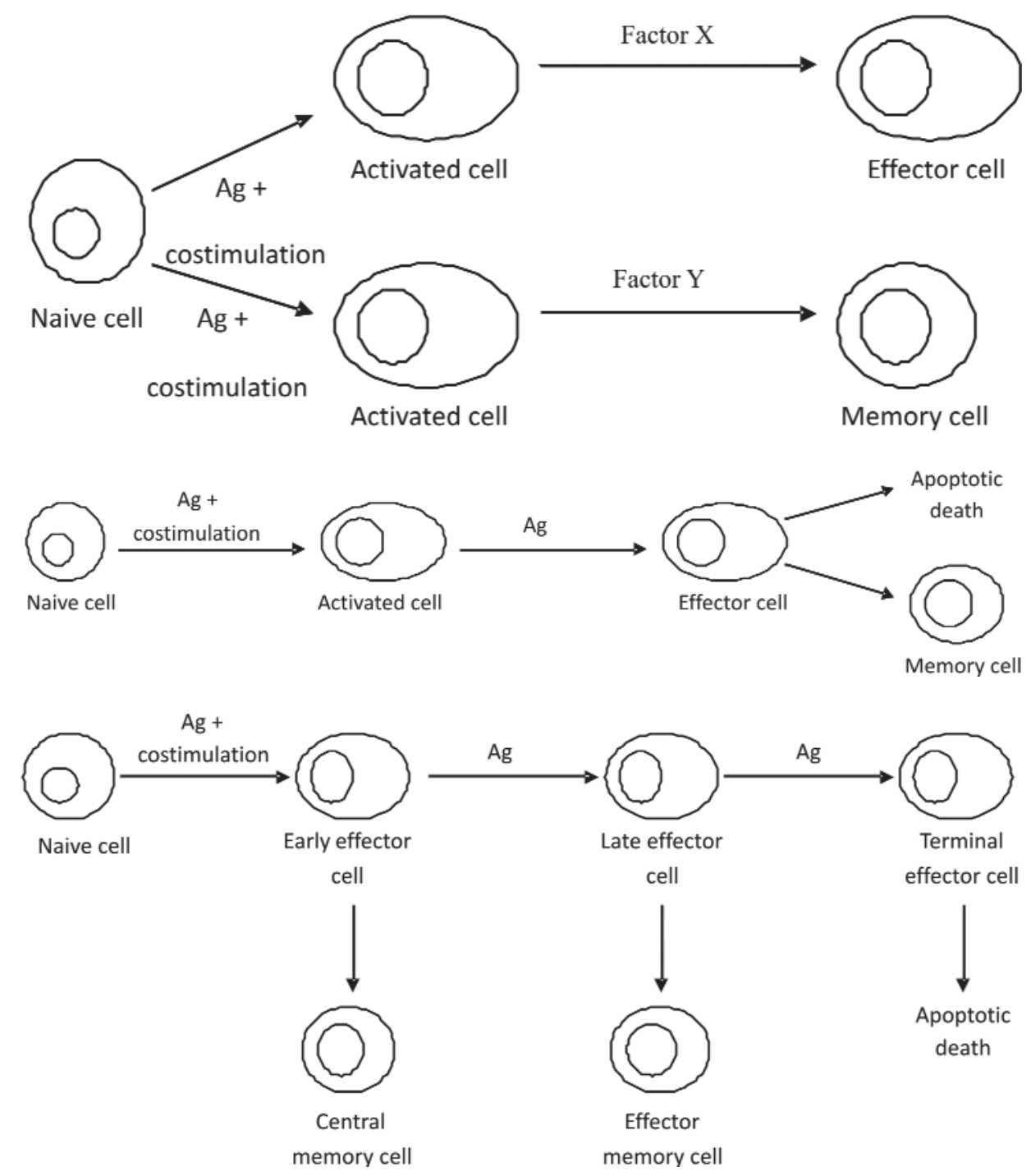

Fig. 2. The model of distinct initial activation [19]. Uniform population of naive precursors upon distinct conditions of initial activation, (antigen $(\mathrm{Ag})+$ costimulation and factor $\mathrm{X}$ or factor $\mathrm{Y}$ ), become effector or memory cells.

Fig. 3. Linear development of effector and memory T cells [17]. Memory cells are derived directly from effector cell.
Within CD8+ T cells similarly to memory CD4+ T cells may be defined as central memory cells $(\mathrm{CCR} 7+)$ and effector (CCR7-). CCR7+ cells express high level of CD62L while the majority of the CCR7- memory cells lack CD62L [3]. Moreover, effector memory $\mathrm{CD} 8+\mathrm{T}$ cells $\mathrm{T}_{\mathrm{EMRA}}$ has been defined based on expression of the cell surface molecule commonly used to differentiate naive and memory $\mathrm{T}$ cells CD45RA [37] (Table 1).

The identification of the memory CD8+ $\mathrm{T}$ cells based on the expression of CD28 and CD95 allows to differentiation of $\mathrm{T}_{\mathrm{CM}}(\mathrm{CD} 28+/ \mathrm{CD} 95+), \mathrm{T}_{\mathrm{EM}}(\mathrm{CD} 28$ $/ \mathrm{CD} 95+)$ and $\mathrm{T}_{\mathrm{N}}(\mathrm{CD} 28+/ \mathrm{CD} 95-)$ [38]. Presence of $\mathrm{T}_{\mathrm{N}}$ can indicate, that not all cells which survived during the second phase of immune response differentiate into $\mathrm{T}_{\mathrm{CM}}$ and $\mathrm{T}_{\mathrm{EM}}$.

In line with distinct of expression cell surface markers memory $\mathrm{T}$ cells exhibit different localization. $\mathrm{T}_{\mathrm{CM}}$ preferentially circulates through secondary lymphoid organs and a place of their main localization is the spleen, blood and lymph nodes. However $\mathrm{T}_{\mathrm{EM}}$ are present in the blood, spleen and peripheral nonlymphoid tissues [32].

$\mathrm{T}_{\mathrm{CM}}$ and $\mathrm{T}_{\mathrm{EM}}$ can be distinguished on the basis of their activation status. $\mathrm{T}_{\mathrm{CM}}$ represents considerable properties of proliferation in response to reinfection $[5,39]$. They lack of immediate effector properties to a Ag stimulation, nevertheless express effector activity to reexsposure to $\mathrm{Ag}[30,39]$. $\mathrm{T}_{\mathrm{CM}} \mathrm{CD} 4+$ have a capacity to synthesize a large quantities of IL-2 [40]. $\mathrm{T}_{\mathrm{EM}}$ provide a immediate response to a reinfection and exhibit direct lytic activity [40]. They have the potential to produce cytokines rapidly and eliminate infected cells $[19,40]$. $\mathrm{T}_{\mathrm{EM}} \mathrm{CD} 8+$ efficiently produce IFN$\gamma$, TNF- $\alpha$, IL-4, IL-5 and perforins [14,41].

Distinct features of phenotypes memory CD4+ and $\mathrm{CD} 8+\mathrm{T}$ cells influence on different functions they display in immune response [23]. $\mathrm{T}_{\mathrm{EM}}$ are considered to provide a first line of defense against Ag, because they are able to extravasate into peripheral tissues and they 
Table 1. Subsets of memory T cells: central memory $\left(\mathrm{T}_{\mathrm{CM}}\right) \mathrm{T}$ cells, effector memory $\left(\mathrm{T}_{\mathrm{EM}}\right) \mathrm{T}$ cells and effector memory RA $\left(\mathrm{T}_{\mathrm{EMRA}}\right) \mathrm{T}$ cells [14]. Hi - high level of expression; lo - low level of expression.

\begin{tabular}{|c|c|c|c|}
\hline \multirow[b]{2}{*}{ CD $4+\mathrm{T}$ cells } & $\mathrm{T}_{\mathrm{CM}}$ & \multicolumn{2}{|c|}{$\mathrm{l}_{\mathrm{EM}}$} \\
\hline & $\begin{array}{c}\text { CD45RA- } \\
\text { CD62I, hi } \\
\text { CCR7+ }\end{array}$ & \multicolumn{2}{|c|}{$\begin{array}{c}\text { CD45RA- } \\
\text { CD62I, hi/lo } \\
\text { CCR7- }\end{array}$} \\
\hline & $\mathrm{T}_{\mathrm{CM}}$ & $\mathrm{T}_{\mathrm{EM}}$ & $\mathrm{l}_{\text {EMRA }}$ \\
\hline CD8+ T cells & $\begin{array}{l}\text { CD } 45 R A- \\
\text { CD62L hi } \\
\text { CCR7+ }\end{array}$ & $\begin{array}{l}\text { CD } 45 \text { RA- } \\
\text { CD } 62 \mathrm{~L} \text { lo } \\
\text { CCR7- }\end{array}$ & $\begin{array}{c}\text { CD45RA+ } \\
\text { CD62L lo } \\
\text { CCR7- }\end{array}$ \\
\hline
\end{tabular}

exert strong elaboration of effector functions [23,30]. Whereas $\mathrm{T}_{\mathrm{CM}}$ with the increased proliferative capacity generate a second wave of effector cells and they are responsible for maintaining long-term protection upon reinfection [31]. Moreover, $\mathrm{T}_{\mathrm{CM}}$ provide the effective protective immunity following either systemic or peripheral challenge because the proliferative capacity of $\mathrm{T}_{\mathrm{CM}}$ results in a larger pool of secondary effector cells $[7,11]$.

The majority of $\mathrm{T}$ cells recirculate continuously from the blood to tissues and then return to the circulation, it one to two times per day occurs [42]. The lymphocyte recirculation is a reflection of unceasingly readiness of organism to recognize and respond to $\mathrm{Ag}$. It ensures higher probability for recognition of $\mathrm{Ag}$ and it's necessary for it's total removal [36]. Thanks to a lymphocyte trafficking the systemic immune responses upon integration and control [42].

Lymphocyte recirculation isn't randomly but is determined by the expression of homing receptors [4345]. Lymphocytes at different states of differentiation or isolated from distinct tissues reveal significant heterogeneity in homing molecule expression whereby the migratory patterns of these cells may be different $[4,16]$.

Naive T lymphocytes recirculate between the blood and lymph, they enter secondary lymphoid organs such as: lymph nodes (LNs), Peyer's patches (PPs) and spleen via high endothelial venules (HEV) and spend about a day in this location before returning to the circulation through thoratic $[36,42]$. The naive $\mathrm{T}$ cells preserve this pattern of recirculation thanks to expression of a specific combination of chemokine receptors and adhesion molecules [2]. Naive T cells express high levels of CD62L, $\beta 2$ integrin (LFA-1), the lymphoid chemokine CCL21 and intracellular adhesion molecule (ICAM1/2) and are CCR7 positive, but low levels of CD11a/CD18 integrin [36]. These cells because of limited expression of other chemokine receptors and adhesion molecules are unable to extravasate into nonlymphoid tissues [2]. Naive T cells home efficiently to lymphoid organs, but they don't enter sites of inflammation [17].

After activation the naive memory cells proliferate rapidly, acquire effector properties and give a rise of effector and memory cells which again undertake migration [17]. Effector T cells require direct contact with the target cell for the effective providing of their function, that's why they need the ability to migrate to different sites of inflammation [17].

\section{Summary}

The memory T cells are found in lymphoid and nonlymphoid tissues [27]. $\mathrm{T}_{\mathrm{CM}}$ exhibit expression of CD62L, CCR7, CCR4, CCR6, CXCR3, CCR1, CCR2 and they are present in secondary lymphoid organs while the part of these cells can circulate between the blood and lymphoid organs like the naive cells do [14,27]. $\mathrm{T}_{\mathrm{CM}}$ are also capable of entering peripheral sites of inflammation [17]. $\mathrm{T}_{\mathrm{EM}}$ don't exhibit expression of CD62L and CCR7, that's why they enter lymph nodes through afferent limphatics $[1,17]$. These cells are able to migrate to nonlymphoid tissue, where the inflammation process is ongoing $[2,7,34] . \mathrm{T}_{\mathrm{EM}}$ express a high expression level of $\beta 1$ and $\beta 2$ integrin and molecule involved in lymphocyte homing into the skin - cutaneous lymphocyte antigen (CLA) and the chemokines receptors such as CCR1, CCR3, CCR5 [2]. The T memory cells homing to skin exhibit expression of the CCR4 and CCR10 [36,41]. Moreover memory T cells homing into gut exhibit expression of $\alpha 4 \beta 7$ integrin and CCR9 $[31,36]$.

Memory $\mathrm{T}$ cells constitute a heterogeneous population of cells which exhibit significant differences in comparison to naive $\mathrm{T}$ cells in terms of their phenotypes and functional properties. These differences are important for secondary immune response. The formation process and precise defining functional properties of these cells is not well understood.

\section{References}

[1] Sprent J, Tough DF. Lymphocyte life-span and memory. Science. 1994;265:1395-1400.

[2] Paul WE. Fundamental Immunology 4th Edition. Philadelphia, PA, USA: Lippincott Williams \& Wilkins; 2003.

[3] Sallusto F, Lenig D, Forster R, Lipp M, Lanzavecchia A. Two subsets of memory $\mathrm{T}$ lymphocytes with distinct homing potentials and effector functions. Nature. 1999;401:708-712.

[4] Beverley PCL. Primer: making sense of T-cell memory. Nat Clin Pract Rheumatol. 2008;4:43-49.

[5] Sprent J, Tough DF. T cell death and memory. Science. 2001;293;245-248.

[ 6] Dauner JG, Williams IR, Jacob J. Differential microenvironment localization of effector and memory CD8 T cells. $J$ Immunol. 2008;180:291-299.

[7] Carton DM, Rusch LK, Hataye J, Itano AA, Jenkins MK. $\mathrm{CD} 4+\mathrm{T}$ cells that enter the draining lymph nodes after anti- 
gen injection participate in the primary response and become central-memory cells. $J$ Exp Med. 2006;203:1045-1054.

[ 8] Nejembi MP, Teijaro JR, Patke DS et al. Control of memory CD4 T cell recall by the CD28/B7 costimulatory pathway. $J$ Immunol. 2006;177:7698-7706.

[ 9] Gourley TS, Wherry EJ, Masopust D, Ahmed R. Generation and maintenance of immunological memory. Semin Immunol. 2004; 16:323-333

[10] Lanzavecchia A, Sallusto F. Dynamics of T lymphocyte responses: intermediates, effectors, and memory cells. Science. 2000;290:92-97.

[11] Wherry EJ, Ahmed R. Memory CD8 T-Cell differentiation during viral infection. J Virol. 2004;78:5535-5545.

[12] Ahmed R, Gray D. Immunological memory and protective immunity: understanding their relation. Science. 1996;272: 54-60.

[13] Slifka MK, Whitton JL. Activated and memory CD8+ T cells can be distinguished by their cytokine profiles and phenotypic markers. J Immunol. 2000;164:208-216.

[14] Weninger W, Manjunath N, von Adrian UH. Migration and differentiation of CD8 T cells. Immunol Rev. 2002;186:221233.

[15] Sprent J. T memory cells: quality not quantity dispatch. Curr Biol. 2002;12:R174-R176.

[16] Ahmadzadeh M, Hussain SF, Farber DL. Heterogeneity of the memory CD4+ cell response: persisting effectors and resting memory T cells. J Immunol. 2001;166:926-935.

[17] Weninger W, Crowley MA, Manjunath N, von Andrian UH. Migratory properties of naive, effector, and memory CD8 cells. J Exp Med. 2001;194:953-966.

[18] Radcliffe JN, Roddick JS, Stevenson FK, Thirdborough SM. Prolonged antigen expression following DNA vaccination impairs effector CD8+ T cell function and memory development. J Immunol. 2007;179:8313-8321.

[19] Kalia V, Sarkar S, Gourley TS, Rouse BT, Ahmed R. Differentiation of memory B and T cells. Curr Opin Immunol. 2006; 18:255-264

[20] Hogan RJ, Usherwood EJ, Zhong W et al. Activated AntigenSpecific CD8+ T Cells Persist in the Lungs Following Recovery from Respiratory Virus Infections. J Immunol. 2001;166: 1813-1822.

[21] Seder RA, Ahmed R. Similarities and differences in CD4+ and CD8+ effector and memory cells generation. Nat Immunol. 2003;4:835-842.

[22] Zanetti M, Franchini G. T cell memory and protective immunity by vaccination: is more better? Trends Immunol. 2006; 27:511-517

[23] Stemberer C, Neuenhahn M, Buchholz VR, Busch DH. Origin of CD8+ effector and memory cell subsets. Cell Mol Immunol. 2007;4:399-405.

[24] Ganusov VV. Discriminating between Different Pathways of Memory CD8+ T Cell Differentiation. J Immunol. 2007;179: 5006-5013.

[25] Crotty S, Ahmed R. Immunological memory in humans. Semin Immunol. 2004;16:197-203.

[26] Bouneaud C, Garcia Z, Kourilsky P, Pannetier C. Lineage relationships, homeostasis, and recall capacities of centraland effector-memory CD8 T cells in vivo. J Exp Med. 2005; 201:579-590.

[27] Obhrai JS, Oberbarnscheidt MH, Hand TW, Diggs L, Chalasani G, Lakkis F. Effector T cell differentiation and memory $\mathrm{T}$ cell maintenance outside secondary lymphoid organs. J Immunol. 2006;176:4051-4058.
[28] Selin LK. Lymphocyte effector functions Memory and unique subsets of lymphocytes. Curr Opin Immunol. 2004;16:257-258.

[29] Lanzavecchia A, Sallusto F. Understanding the generation and function of memory T cell subsets. Curr Opin Immunol. 2005; 17:326-332.

[30] Kopec-Szlęzak J. Subpopulacje limfocytów T. Onkol Pol. 2005;8:17-20.

[31] Hikono H, Kohlmeier JE, Scott I, Roberts AD, Blackman MA, Woodland DL. T-cell memory and recall responses to respiratory virus infections. Immunol Rev. 2006;211:119-132.

[32] Hikono H, Kohlmeier JE, Takamura S, Wittmer ST, Roberts $\mathrm{AD}$, Woodland DL. Activation phenotype, rather than centralof effector- memory phenotype, predicts the recall efficacy of memory CD8+ T cells. J Exp Med. 2007;204;1625-1636.

[33] Klonowski KD, Marzo AL, Williams KJ, Lee S, Pham Q, Lefrancois L. CD8 T cell recall responses are regulated by the tissue tropism of the memory cell and pathogen. J Immunol. 2006;177:6738-6746.

[34] Masopust D, Vezys V, Marzo AL, Lefrancois L. Preferential localization of effector memory cells in nonlymphoid tissue. Science. 2001;291:2413-2417.

[35] Moulton VR, Bushar ND, Leeser DB, Patke DS, Farber DL. Divergent generation of heterogeneous memory CD4 T cells. J Immunol. 2006;177:869-876.

[36] Fearon DT, Manders P, Wagner SD. Arrested differentiation, the self-renewing memory lymphocyte, and vaccination. Science. 2001;293:248-250.

[37] Willinger T, Freeman T, Hasegawa H, McMichael AJ, Callan MFC. Molecular signatures distinguish human central memory from effector memory CD8 T cell subsets. $J$ Immunol. 2005; 175:5895-5903.

[38] Vaccari M, Trindade CJ, Venzon D, Zanetti M, Franchini G. Vaccine- induced CD8+ central memory $\mathrm{T}$ cell in protection from Siman AIDS. J Immunol. 2005;175; 3502-3507.

[39] Sprent J, Surh CD. Generation and maintenance of memory T cells. Curr Opin Immunol. 2001;13:248-254.

[40] Stemberger C, Neuenhahn M, Buchholz VR, Busch DH. Origin of CD8+ effector and memory T cell subsets. Cell Mol Biol. 2007;4:339-405.

[41] Humphreys TL, Baldridge LA, Billings SD, Campbell JJ, Spinola SM. Trafficking pathways and characterization of CD4 and CD8 cells recruited to the skin of humans experimentally infected with Haemophilus ducreyi. Infect Immun. 2005;73:3896-3902.

[42] Butcher EC, Picker LJ. Lymphocyte homing and homeostasis. Science. 1996;272:60-66.

[43] Haegele KF, Stueckle CA, Malin JP, Sindern E. Increase of CD8+ T-effector memory cells in peripheral blood of patients with relapsing-remitting multiple sclerosis compared to healthy controls. J Neuroimmunol. 2006;183:168-174.

[44] Hengel RL, Thaker V, Pavlick MV et al. Cutting edge: Lselectin (CD62L) expression distinguishes small resting memory $\mathrm{CD} 4+\mathrm{T}$ cells that preferentially respond to recall antigen. $J$ Immunol. 2003;170:28-32.

[45] Cyster JG. Chemokines and cell migration in secondary lymphoid organs. Science. 1999;286:2098-2102.

[46] Tomiyama H, Matsuda T, Takiguchi M. Differentiation of human CD8+ T cells from a memory to memory/effector phenotype. J Immunol. 2002;168:5538-5550.

Submitted: 9 May, 2008 Accepted after reviews: 18 June, 2008 